\title{
The Role of Canada's
}

Associate Committee on

\section{Forest Fire Protection}

\author{
by W.H. N. McGuffin
}

The Associate Committee on Forest Fire Protection is a unique organization in that its membership includes senior personnel from provincial and federal governments as well as representatives of forest industry, forest protective associations and university forestry faculties - those who are both experts and decision-makers in forest fire control. In the 16 years since it was formed the committee has proved a valuable forum for considering problems of mutual concern to its members, for indicating areas in which research is required, and for coordinating forest fire control activities throughout Canada.

Since it was established in 1953 the Associate Committee on Forest Fire Protection has played a significant role in co-ordinating and developing all aspects of forest fire control in Canada.

As its name implies, it functions as an associate committee of the National Research Council. Under its terms of reference there are three main objectives for the committee's activities:

a) furthering research into forest fire control in Canada;

b) serving as liaison between the National Research Council and government, educational and other organizations and agencies engaged in or concerned with research in forest fire control; and

c) recommending to the appropriate agencies research projects which should be undertaken in this field.

While the objectives of the committee are specifically oriented to research, over the past 16 years the connotation has been broadened somewhat. Much of the committee's work has been concerned with relative short-term operational and equipment analysis projects, and considerable attention has been given as well to the need for basic or background fire research involving longer periods of time.

The committee deals with a broad range of specific matters such as fire control training programs, mutual aid arrangements for exchanging manpower, equipment and aircraft, education, publicity and many other matters which might not be clearly defined as research, but as it is the only national committee concerned with forest fire control it has assumed these responsibilities.

Perhaps the greatest value of the Associate Committee on Forest Fire Protection is that it is the only existing organization in Canada which includes in its membership senior representatives from provincial governments, the federal government, as well as other agencies who are both experts and de-
Forestry Information Service

Con. Dept. of Fisheries

and Forestry

Ottowa

ODC $43(71)$.

cision-makers in fire control. The committee provides a national and co-ordinated approach to fire control and also acts as a sounding board for interests and problems of mutual concern to the participating agencies.

As presently constituted the Associate Committee has some 20 members, including the heads of government forest protection organizations in British Columbia, Alberta, Saskatchewan, Manitoba, Ontario, Quebec, New Brunswick, Nova Scotia, Newfoundland, the Yukon and Northwest Territories, forest industry, forest protective associations, and representatives from university forestry faculties, federal departments and the National Research Council.

The Forestry Branch of the Department of Fisheries and Forestry and the National Research Council together provide a permanent joint secretariat. The committee meets annually, most recently at Ottawa on January 28, 29 and 30 of this year. But as might be expected, the bulk of its work derives from the activities of a number of sub-committees. A brief review of the functions of these sub-committees will give a fuller picture of the aims and accomplishments of the Associate Committee.

One sub-committee has produced a glossary of fire control terminology which has proved of great value in facilitating communications between the different jurisdictions in Canada. This glossary is published in both the official languages.

Another sub-committee is responsible for the improvement of co-operation between agencies and has recommended the preparation and maintenance of a listing of the names and telephone and Telex numbers of senior fire control personnel throughout Canada. The value of such a list can be readily appreciated in emergency situations where assistance in the form of personnel and equipment is urgently required from another jurisdiction, and plans are underway for expanding this into a full directory.

Standardization of fire control equipment is the objective of another of the sub-committees. This will result in prescribed standards of quality for a wide range of items. Again, this standardization is of proven value in mutual aid arrangement and also can result in financial savings.

Then there is the standardizing of radio communications facilities for fire control teams. This includes the manufacture and types of radios used and the range of frequencies on which they operate, both on the ground and in aircraft, a prerequisite for effective mutual assistance. Other sub-committees are concerned with correlating forest fire 


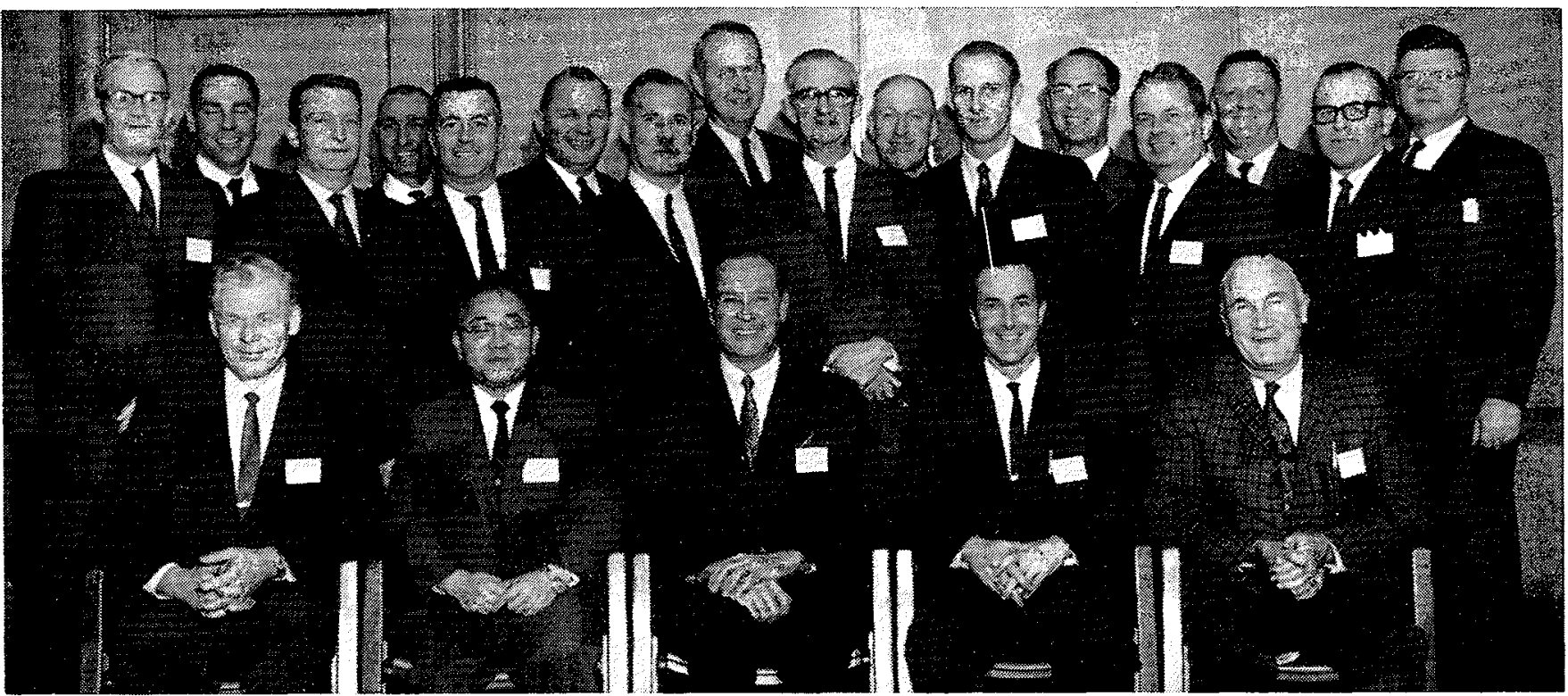

Front Row (seated) - members of the committee's executive, from left to right - H. J. Irving, vice chairman (manager, Gatineau Forest Protective Association); Dr. K. Sumi, joint secretary (Division of Building Research, National Reseorch Council); S. R. Hughes, chairman (Administrator, Forest Protection, Alberta Department of Lands and Forests); D. E. Williams, joint secretary (Director, Forest Fire Research Institute, Department of Fisheries and Forestry); D. A. Wolstenhalme, past chairman (Director, Forest Protection Branch, New Brunswick Department of Lands and Mines).

Back Row (standing) _ from left to right - R. R. Ross (Forest Protection Division, Manitoba Department of Mines and Natural Resources); R. G. McCullough (Forests Branch, New Brunswick Department of Mines and Natural Resources); R. J. Hatcher (Woodlands Section, Canadian Pulp and

statistics so that meaningful figures can be produced on a national basis, public relations and publicity, and with making representations to manufacturers on new types of equipment which are required.

Another sub-committee, concerned with standards of training for fire control crews, is currently working towards production of a universal training manual. This group is also endeavouring to have university faculties of forestry devote more time and attention in their curricula to specialized studies of forest fire suppression and control.

The Associate Committee can point to a number of other notable achievements resulting from its activities. It was instrumental in initiating the studies which led to the development of the infrared scanner in Canada for spotting forest fires from the air, and which is now being manufactured commercially. It has initiated a number of studies into the development and use of aircraft and airborne equipment for maximum effectiveness in combatting forest fires. It has directed attention to research into the economics of forest fire control - how to apportion expenditures to achieve the most effective return per dollar spent, the value of pre-suppression as compared to suppression measures, etc.

A continuing research program first proposed by
Poper Associotion); T. O. Dupuis (Manager, Ottowa Forest Protective Association); L. Leblanc (Forest Protection Service, Quebec Department of Lands and Forests): Dr. N. L. Kissick (Faculty of Forestry, University of New Brunswick); A. D. Hall (Executive Secretary, Canadian Forestry Association); W. T. Foster, (Chief, Forest Protection Branch, Ontorio Department of Lands and Forests); R. T. Flanagan (National Parks Branch, Department of Indian Affairs and Northern Development); L. A. Corkum (Supervisor of Forest Protection, Nova Scotia Department of Lands and Forests); Dr. D. G. Gould (National Aeronautical Establishment, National Research Council); W. C. Phillips (Chief, Protection Civision, British Columbia Forest Service); G. W. Shorter (Division of Building Research, National Research Council); J. A. Doyle (Chief Forest Ranger, Newfoundland Department of Mines, Agriculture and Resources); P. L. Morais (Manager, Price Forest Protective Association Ltd.); R. B. Laughlan (Manager, Ontario Forest Industries Association).

the committee is seeking to reduce the forest fire hazard from power saw engines and mufflers. The committee was responsible for initiating a test procedure which ensures the periodic testing of the quality of hoses, one of the most expensive aspects of forest fire control due to the large quantities which are used. Standardizing of the couplings for fire hoses was another achievement, as is the greatly expanded use of forest fire simulators in Canada for the training of fire control personnel.

At its most recent meeting the Associate Committee spent some time considering recent developments in meteorology which could play an important role in forest fire control in the not-too-distant future. Officials of the Meteorology Branch of the federal Department of Transport advised the committee of the more extensive weather forecasting which has become possible through the use of weather satellites, and of the possibilities of pinpointing sudden temperature changes on the earth's surface through the use of infra-red sensing devices on the satellites. The committee was also advised of the extensive computerized climatological archives which have been organized and are being maintained by the Meteorological Branch, and of their potential value in fire control, for example in predicting the likely occurrence, severity and extent of drought conditions in a given area. 